\title{
Article
}

\section{Coal Fly Ash-Clay Based Geopolymer-Incorporating Electric Arc Furnace Dust (EAFD): Leaching Behavior and Geochemical Modeling}

\author{
Eva Cifrian, Juan Dacuba, Tamara Llano $\mathbb{D}^{\text {, }}$, María del Carmen Díaz-Fernández and Ana Andrés *
}

Citation: Cifrian, E.; Dacuba, J.; Llano, T.; Díaz-Fernández, M.d.C.; Andrés, A. Coal Fly Ash-Clay Based Geopolymer-Incorporating Electric Arc Furnace Dust (EAFD): Leaching Behavior and Geochemical Modeling. Appl. Sci. 2021, 11, 810. https://doi. org/10.3390/app11020810

Received: 24 December 2020 Accepted: 14 January 2021 Published: 16 January 2021

Publisher's Note: MDPI stays neutral with regard to jurisdictional clai$\mathrm{ms}$ in published maps and institutional affiliations.

Copyright: (C) 2021 by the authors. Licensee MDPI, Basel, Switzerland. This article is an open access article distributed under the terms and conditions of the Creative Commons Attribution (CC BY) license (https:// creativecommons.org/licenses/by/ $4.0 /)$.
Department of Chemistry and Process and Resource Engineering, University of Cantabria, Avda. Los Castros 46, 39005 Santander, Spain; cifriane@unican.es (E.C.); juan.dacuba@alumnos.unican.es (J.D.); llanot@unican.es (T.L.); mayka@telefonica.net (M.d.C.D.-F.)

* Correspondence: andresa@unican.es; Tel.: +34-942-201-589

\begin{abstract}
The recent recovery processes of electric arc furnace dust (EAFD) include stabilization within materials with potential uses in the construction sector. The stabilization of EAFD by alkaline activation of different alumina-silicates, resulting in low-cost and environmentally friendly materials. The leaching standards within the different European regulations allow evaluating waste materials and products. This work aims to study the introduction of EAFD in FA-clay geopolymers, assessing the environmental and geochemical behavior in two different scenarios, disposal, and utilization. For it, the compliance equilibrium-based batch test (EN 12457-2) and pH dependence test (EN 14429) have been used. The dosages of EAFD in the geopolymeric matrix are $5 \%$ to $20 \%$ with curing temperatures of $75^{\circ} \mathrm{C}$ and $225^{\circ} \mathrm{C}$. The introduction of EAFD favors the development of the flexural strength. From the environmental point of view, metals related to EAFD, such as $\mathrm{Zn}, \mathrm{Pb}$, or $\mathrm{Cu}$, are retained in the matrix. While As or Se, comes mainly from clay, present a high concentration. Therefore, the role of clay should be analyzed in future research. As expected by the high iron content in the EAFD, the iron complexes on the surface of the material are responsible for immobilization of metals in this type of matrix.
\end{abstract}

Keywords: electric arc furnace dust; fly ash; ceramic geopolymer; leaching behavior; geochemical modeling

\section{Introduction}

Electric arc furnace dust (EAFD) is generated from the electric arc furnace production of steel in amounts of approximately 1-2\% (by weight) of the steel produced. More than $30 \%$ of steel production now uses electric arc furnaces [1] and approximately 6 million metric tons of EAFD are generated on an annual basis worldwide, and of that amount, only an estimated 2.5 million metric tons are recycled, mainly in the United States, Europe, Taiwan and Japan [2,3]. EAFD is identified as a hazardous waste in the European Waste List and by the US-EPA, as it contains high quantities of $\mathrm{Cd}, \mathrm{Cr}, \mathrm{Pb}$, and $\mathrm{Zn} \mathrm{[4-9].} \mathrm{The}$ "Best Available Techniques (BAT) Reference Document for Iron and Steel Production" [10] includes as EAFD recycling option the pyrometallurgical or hydrometallurgical processes or hybrid of both (Waelz Process). These processes aim, on the one hand, to extract nonferrous metals such as zinc and lead that can be incorporated into other processes, and on the other allow the recycling of the matrix in the steel industry and thus avoid its disposal in landfills. However, despite the high iron content, for waste with less than 15\% of $\mathrm{Zn}$, the most used management continues to be the landfill of hazardous waste after solidification/stabilization treatment. In the EU two-thirds of EAFD generated are deposed in landfills [11,12].

The recent recovery processes of EAFD include stabilization within materials with potential uses in the construction sector. Due to its ability to assimilate alternative materials 
of different nature (without significant changes in the production process) and without negative effects on the properties of the final product. This way of management is the most favorable because of its low cost and environmental benefit of reducing waste, minimizing the impact on the environment by avoiding disposal in landfills, and reducing the amount of natural resources that the activity needs. The stabilization of EAFD is carried out, by vitrification, obtaining a vitreous material [13], or by cementation, with hydraulic binders, a cement matrix [6,14,15], and recently by alkaline activation of different aluminosilicates $[16,17]$, resulting in low-cost and environmentally friendly materials. The manufacturing process of these new cementitious materials, generate less polluting gas emissions and significant energy savings. Among these alternative materials, ceramic geopolymers are a subgroup, where fly ash, with a low calcium content, and calcined clays are the most common precursors used in the synthesis of geopolymers [18]. Ceramic geopolymers can be carried out in two temperature ranges, geopolymers at low temperatures, ranging from room temperature to $450{ }^{\circ} \mathrm{C}$ and those at high temperatures ranging up to $1200^{\circ} \mathrm{C}$. The geopolymers obtained with setting temperatures between $65^{\circ} \mathrm{C}$ and $450{ }^{\circ} \mathrm{C}$, are equivalent to conventional ceramic bricks, stable to water and with medium mechanical resistance [19-21].

Geopolymers that use industrial waste or by-products have the potential to introduce pollutants into the environment. Laboratory leaching tests are applied by different authors to evaluate the degree of immobilization of hazardous materials, as well as to estimate the elimination of toxic trace elements during the beneficial reuse of secondary materials on the ground [22,23]. In this way, leaching tests are basically carried out for the purpose of providing information on material/water contact conditions and their influence on potential release of pollutants to the water of the soil, being an essential stage in the absorption by plants and also in the elimination to water resources. The most used tests are the toxicity characteristic leaching procedure (TCLP, 1992), and the equilibrium batch leaching test (UNE-EN 12457, 2002). Results from these tests are compared respectively, to the threshold limits established by the Environmental Protection Agency (EPA, Washington, WA, USA) and those summarized in the 2003/33/EC Council Decision (EU, 2003), where in the criteria for acceptance of waste at landfill are established. However, logically, a single test cannot provide all the information that is sometimes required, but a few carefully selected tests will be sufficient [24]. Many leaching tests have been designed within different fields with slightly different purposes for different materials. Currently, there is a trend to harmonize leaching standards and test methods within the different European regulations for evaluating waste materials and products-beneficial use according Construction Products Regulations in each Member State [25]; Disposal according with Landfill Decision [26], and future regulation on End of Waste criteria [24]. In this way, in order to link the leaching behavior of the residual material and the exposure conditions, the European standardization organization has developed a framework for application of leaching tests, EN 12920 "Characterisation of waste-Methodology for the determination of the leaching behavior of waste under specified conditions". It is applied in a disposal or utilization scenario within a specified time frame. The methodology is designed to ensure that the specific properties of the waste and the conditions of the scenario are taken into account. The methodology contains several stages, in some of them leaching tests are used. The selection of tests is carried out depending on the objective, that is, the definition of the problem and the search for the solution, the waste under consideration and the scenario to evaluate [27].

In this context, the different leaching tests for the basic characterization of residual material have been selected based on previous recommendations and are important for assessing the release of pollutants into ground and surface water [28]. The leaching behavior depends on several variables such as leachant composition, contact time, and the liquid-to-solid ratio [29]. Equilibrium-based batch tests are low cost because they are relatively simple and rapid and they are normally used as a simple tool for compliance and/or quality control. If leaching under equilibrium-based batch tests occurs at levels 
of potential environmental concern, $\mathrm{pH}$ dependent testing can also be conducted [30]. Total availability for leaching is an important parameter that depends on the matrix and mineralogical phases [31]. The $\mathrm{pH}$ dependent leaching test is a valuable tool to characterize the basic chemical leaching behavior over a wide range of $\mathrm{pH}$ values (much broader than the typical intended use conditions). The $\mathrm{pH}$ dependent leaching test provides data on the behavior of pollutants in relation to $\mathrm{pH}$ and the results can be used in geochemical modeling to identify solubility controlling processes [32,33]. Identifying the chemical processes that occur in leaching will allow considering different options to improve quality and also making a prior estimate of the effects of changes in $\mathrm{pH}$, such as carbonation, on the emission of pollutants [34]. The majority of pollutants show amphoteric behavior, while in some cases oxyanions may also be present and show a different behavior [22,35]. Understanding the mechanisms of leaching and the speciation of individual contaminants is essential for predicting the long-term immobilization of pollutants in waste materials [36]. Modeling and numerical simulation has become essential for environmental risk assessment.

There are few studies in the literature on the effect of EAFD on the properties of OPC and blended cement concrete, with satisfactory results $[6,14]$ unless the objective is to develop a concrete set retarder, as shown in the work recently published [15]. Due to the hazardous nature of EAFD, its use in civil construction should be based on solidification/stabilization technologies. In this way, there are some studies that show the results of incorporating EAFD in processes of geopolymerization of coal fly ash $[16,17,37]$. On the other hand, it should be noted that there is a significant number of published studies that evaluate the environmental implications of geopolymeric systems based on industrial waste through leaching behavior, but exclusively using a leaching test, mostly the TCLP [38-42]. Although geochemical modeling of inorganic waste and stabilized waste has been extensively used, only limited research has determined the chemical species and leaching of oxyanions $[32,35,43,44]$, and only some authors studied the geochemical modeling of FA based geopolymer $[23,38,45]$. It is important to note that there are no published studies where EAFD is incorporated into ceramic geopolymers, based on coal fly ash and quarry clay as precursors. Therefore, there is no research regarding environmental assessment based on different leaching tests for such kind of ceramic geopolymers incorporating EAFD.

This work aims to study environmental and geochemical behavior of FA-clay geopolymers incorporating EAFD, using leaching tests, compliance equilibrium-based batch (EN 12457-2) and $\mathrm{pH}$ dependence (EN 14429:2015), simulating different scenarios, disposal and utilization respectively. The results of leaching of toxic trace elements, $\mathrm{As}, \mathrm{Ba}, \mathrm{Cr}, \mathrm{Cu}$, $\mathrm{Mo}, \mathrm{Ni}, \mathrm{Pb}, \mathrm{Sb}, \mathrm{Se}, \mathrm{Zn}$, and $\mathrm{Cd}$, will be used to predict the long-term release behavior as a function of $\mathrm{pH}$ and chemical speciation modeling for this type of matrices.

\section{Materials and Methods}

\subsection{Raw Materials}

Raw materials used in this study were obtained from different sources of the same region (Cantabria, Spain), most of them from waste flows. Low calcium fly ash (ASTM class F) were supplied by Reciclados De Cabezon S.l. - (Cabezón de la Sal, Cantabria, Spain) and was used as the main silicoaluminate agent. Quarry clay was collected from an industrial brickwork and was used as secondary silicoaluminate source. EAFD were produced by a steel production company, which uses scrap in an electric arc furnace to produce steel of different qualities and supplied by FCC Ámbito S.A. (Guarnizo, Cantabria, Spain) a waste treatment company.

The composition of FA, clay, and EAFD were determined by inductively coupled plasma atomic emission spectrometry (ICP-AES) and X-ray fluorescence (XRF) in Activations Laboratories (Ancaster, ON, Canada). The elemental major and minor oxides and trace element concentrations in raw materials are given in Table 1. Both precursors, FA and clay, are mainly constituted by $\mathrm{SiO}_{2}$ and $\mathrm{Al}_{2} \mathrm{O}_{3}$ while, the EAFD show a predominant 
presence of $\mathrm{Fe}$ and $\mathrm{Zn}$, and to a lesser extent $\mathrm{Pb}$ and $\mathrm{Cr}$, with similar values to those reported by other authors $[17,37,46]$.

Table 1. Major, minor oxides and trace elements in Fa, clay, and EAFD.

\begin{tabular}{cccc}
\hline Raw Materials & FA & Clay & EAFD \\
\hline \multicolumn{2}{c}{ Composition (wt \%) } \\
\hline $\mathrm{SiO}_{2}$ & 52.38 & 64.22 & 4.18 \\
$\mathrm{Al}_{2} \mathrm{O}_{3}$ & 21.32 & 16.93 & 0.98 \\
$\mathrm{Fe}_{2} \mathrm{O}_{3}$ & 6.88 & 5.94 & 33.36 \\
$\mathrm{~K}_{2} \mathrm{O}$ & 2.50 & 3.03 & 1.40 \\
$\mathrm{CaO}$ & 6.23 & 0.52 & 6.71 \\
$\mathrm{MgO}$ & 2.48 & 0.89 & 2.38 \\
$\mathrm{Na} \mathrm{O}_{2} \mathrm{O}$ & 2.02 & 0.58 & 1.88 \\
$\mathrm{TiO}$ & 0.92 & 0.86 & 0.09 \\
$\mathrm{MnO}$ & 0.07 & 0.06 & 2.42 \\
$\mathrm{P}_{2} \mathrm{O}_{5}$ & 0.82 & 0.08 & 0.97 \\
$\mathrm{LOI}$ & 5.39 & 5.78 & 11.33 \\
\hline & \multicolumn{2}{c}{ Composition $\mathbf{( m g} / \mathbf{k g})$} & 39.50 \\
$\mathrm{As}$ & 44 & 30 & 477 \\
$\mathrm{Ba}$ & 2662.25 & 483 & 260 \\
$\mathrm{Cd}$ & 1.10 & 0.50 & 2040 \\
$\mathrm{Cr}$ & 76.25 & 46 & 2030 \\
$\mathrm{Cu}$ & 85.75 & 27 & n.d. \\
$\mathrm{Hg}$ & n.d. & n.d. & 35.10 \\
$\mathrm{Mo}$ & 18 & 2 & 150 \\
$\mathrm{Ni}$ & 129 & 29 & 23,000 \\
$\mathrm{~Pb}$ & 52.50 & 28 & 136 \\
$\mathrm{Sb}$ & 7.80 & 2.5 & 259,000 \\
$\mathrm{Se}$ & 0.55 & 0.02 &
\end{tabular}

n.d. not determined.

Figure 1 shows the FA and clay mineralogical results obtained by XRD Bruker D8 advance equipment fitted with a $\mathrm{Cu}$ tube with a wavelength of $1.541810^{-10} \mathrm{~m}$. The X-ray powder diffraction pattern have been fitted using the pattern matching routine in the DIFFRACplus EVA program supplied by Bruker. A halo is observed between $20^{\circ}$ and $35^{\circ}$ due to the vitreous nature of FA sample. However, this halo is not observed in the clay sample, which means that the amount of amorphous silica that can react is very small due to the mineralogy of its components is mainly crystalline.

Fly ash and quarry clay was activated by an alkaline solution prepared by mixing $\mathrm{Na}_{2} \mathrm{SiO}_{3}$ and $\mathrm{NaOH}$ solutions. Sodium silicate solution $\left(\mathrm{Na}_{2} \mathrm{O}=8.5 \%, \mathrm{SiO}_{2}=28.5 \%\right.$, and density of $1.4 \mathrm{~g} / \mathrm{cm}^{3}$ ) was a commercial water glass supplied by Panreac AppliChem, Santander, Spain, and sodium hydroxide solution was obtained by dissolving solid $\mathrm{NaOH}$ pellets ( $99 \%$ purity) in deionized water. 


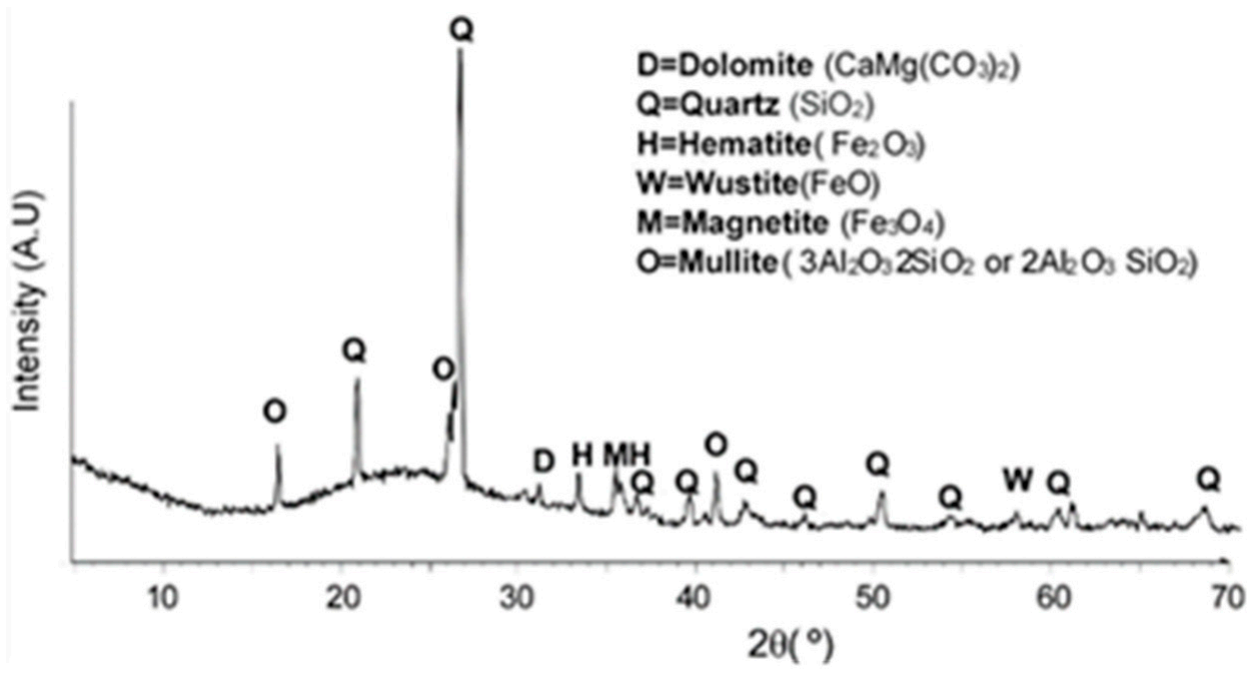

(a)

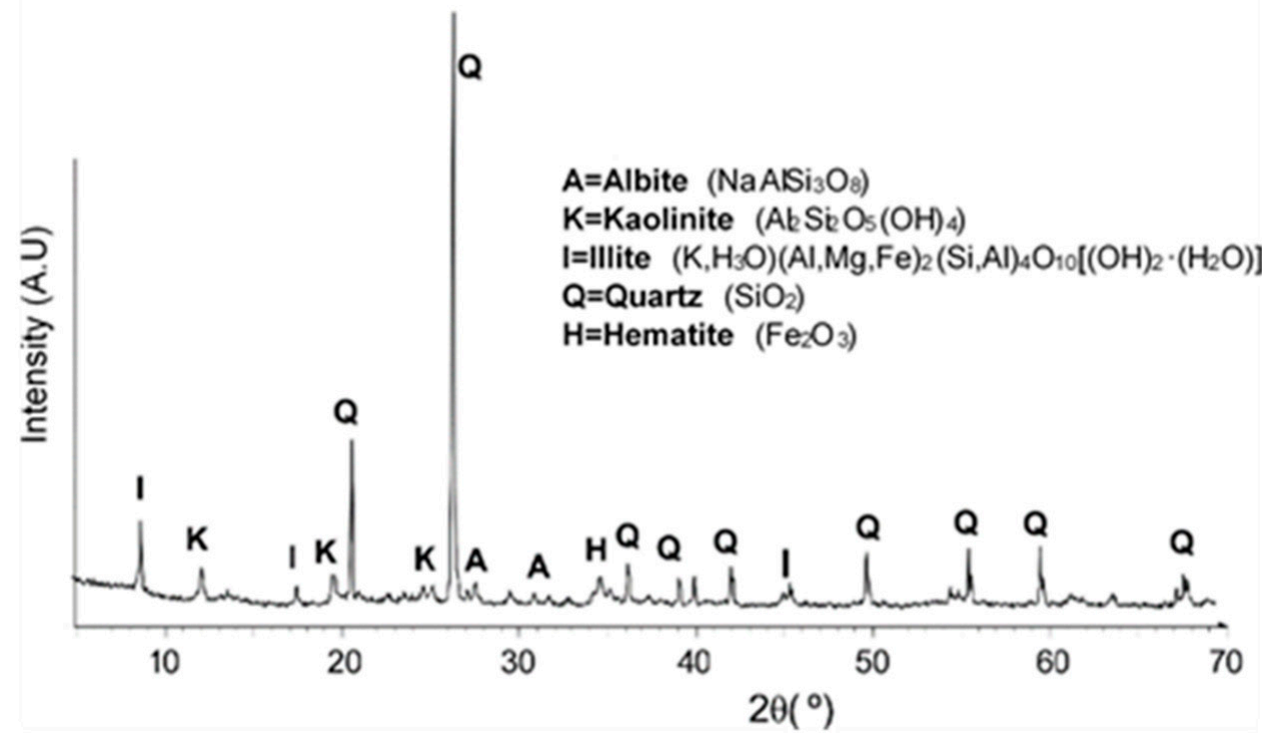

(b)

Figure 1. XRD pattern of FA (a) and clay (b).

\subsection{Sample Preparation}

Samples were prepared by mixing weighted solid precursor, an alkali activator and deionized water in a mixer. The geopolymer matrix was formed by an aluminosilicate source, FA, and clay, with an FA/clay ratio of 0.7 . Liquid phase corresponds to the activator solution mixture of sodium hydroxide and sodium silicate, with a $\mathrm{NaOH}$ concentration of $6 \mathrm{M}$ and $\mathrm{Na}_{2} \mathrm{SiO}_{3} / \mathrm{NaOH}$ ratio of 0.4. Liquid/FA ratio used was 0.6. However, the water content was adjusted to achieve the same workability in all the mixtures. EAFD was added to the starting mixtures replacing clay content in quantities of $0 \%, 5 \%, 10 \%, 15 \%$, and $20 \%$, while keeping constant the amount of FA. Curing temperatures were $75^{\circ} \mathrm{C}$ and $225^{\circ} \mathrm{C}$ for $48 \mathrm{~h}$ and the test were conducted after 14 days.

The sample development is described below. Solids were mixed for $10 \mathrm{~min}$ before the addition of the activator solution in order to obtain a homogeneous mixture. The $6 \mathrm{M} \mathrm{NaOH}$ solution was prepared and cooled to room temperature, then $\mathrm{Na}_{2} \mathrm{SiO}_{3}$ was added up to $\mathrm{Na}_{2} \mathrm{SiO}_{3} / \mathrm{NaOH}$ ratio fixed. At the end, activator solution was added into the mixture of FA-clay-EAFD, and mixing was continued for additional $10 \mathrm{~min}$. Specimens were obtained by uniaxial pressing under 50 bar with a Mignon SS/EA (Nanetti) laboratory a hydraulic press in a rectangular mold with $80 \mathrm{~mm}$ in length, $30 \mathrm{~mm}$ in width and $16 \mathrm{~mm}$ in height. 
Samples were stored in ambient temperature $\left(18-20^{\circ} \mathrm{C}\right)$ for $48 \mathrm{~h}$. After this time, they were cured in the oven for $48 \mathrm{~h}$ at $75^{\circ} \mathrm{C}$ and $225^{\circ} \mathrm{C}$. Then, the samples were cooled and left for an additional 14 days at ambient temperature prior to performing any test.

\subsection{Geopolymer Characterization}

Water absorption was determined with the UNE 67-027 standard by immersing the piece in water, at atmospheric pressure and room temperature, until saturation occurs.

The UNE-EN 843-1 standard was used to determine the flexural strength of the bricks. This test was conducted by a servo hydraulic mechanical equipment of pressure cell Suzpecar MES-150 15-ton capacity equipped with an electronic control module MIC-101 $\mathrm{H}$. The study of both properties has been carried out in triplicate and the results show the mean and its standard deviation.

Morphological characterization was carried out using a JEOLJSM 840 scanning electron microscope (SEM) (University of Cantabria, Spain). Samples were studied on SEM stubs with a sticky carbon cover and then coated with carbon.

\subsection{Leaching Tests}

The immobilization of metals from EAFD and other raw materials was assessed from the chemical point of view according to three leaching tests: NEN 7371, UNE EN 12457-2, and UNE EN 14429.

The availability leaching test NEN 7371:2004 was aimed to determine the maximum amount of contaminant which can be leached from the material under extreme conditions. The test was performed on finely ground material $(<125 \mu \mathrm{m})$ at a high dilution (liquid/solid $50 / 1$ ) by controlling the $\mathrm{pH}$ at 7 for $3 \mathrm{~h}$ and subsequently at $\mathrm{pH} 4$ for another $3 \mathrm{~h}$ using $\mathrm{NO}_{3} \mathrm{H} 1 \mathrm{M}$. Deionized water was used as leachant.

The equilibrium leaching test UNE EN 12457-2:2003 was used to determine the concentration of metals leached from the materials in the equilibrium. Samples were milled to below $4 \mathrm{~mm}$ to promote contact and leaching of trace elements. The leaching test was performed in deionized water as the leachant with liquid/solid ratio $=10$ and $24 \mathrm{~h}$ stirring.

The $\mathrm{pH}$ dependence leaching test UNE EN 14429:2015 was used to characterize the influence of $\mathrm{pH}$ in the leaching of inorganic components of waste. Samples were milled to below $1 \mathrm{~mm}$. Parallel batch extractions with a liquid/solid ratio $=10$ with additions of acid or base to attain specific endpoint $\mathrm{pH}$ values; at least eight different $\mathrm{pH}$ points were reached, ranging from $\mathrm{pH} 2$ to $\mathrm{pH} 12$ by using $\mathrm{NO}_{3} \mathrm{H}(0.1 \mathrm{M}$ to $5 \mathrm{M})$ or $\mathrm{NaOH}(0.1 \mathrm{M}$ to $5 \mathrm{M})$.

At the end of each test, samples were filtered, and the leachates were analyzed. The $\mathrm{pH}$ was measured and metal concentrations in the leachates were determined by inductively coupled plasma-collision cell-mass (ICP-MS). All leaching test were carried out in duplicate.

\subsection{Geochemical Modeling}

The geochemical modeling under equilibrium conditions was undertaken for the interpretation of the contaminant mobilization as a function of $\mathrm{pH}$. The application of predictive geochemical modeling using Visual MINTEQ 3.0 software (KTH, Sweden) was performed to explain the $\mathrm{pH}$-dependent leaching behavior of the trace elements. Major and minor components presented in EAFD, FA, and clay were introduced in the model. Input files were completed with the maximum leached concentrations of the geopolymers. Initial species and mineralogical phases were determined based on the literature and the availability and mobility results.

The main steps in geochemical modeling has involve: (i) selection of the interest elements, major cations, and other ions that have a profound effect on the solubility on the trace elements; (ii) establishing the mineral set by means of experimental and other modeling studies; (iii) preliminary simulations to determine the oxidation states of the elements and the presence of solubility controlling species; (iv) modeling of the $\mathrm{pH}$ dependent leaching behavior through predictive simulations taking into account aqueous 
specification and complexation reactions, mineral dissolution and precipitation reactions, and surface complexation reactions onto Fe surface (HFO); and (iv) validation the models by comparing the results with the experimental data [47].

\section{Results and Discussion}

\subsection{Geopolymer Characterization}

The technological behavior of the geopolymer with EAFD has been studied based on its water absorption and flexural strength for the two studied curing temperatures of $75^{\circ} \mathrm{C}$ and $225^{\circ} \mathrm{C}$. Table 2 shows the evolution of the two properties with the dosage of EAFD and the temperature.

Table 2. Evolution of water absorption and flexural strength for geopolymers with EAFD at $75^{\circ} \mathrm{C}$ and $225^{\circ} \mathrm{C}$.

\begin{tabular}{ccccc}
\hline \multirow{2}{*}{ \% EAFD } & \multicolumn{2}{c}{ Water Absorption (\%) } & \multicolumn{2}{c}{ Flexural Strength (MPa) } \\
\cline { 2 - 5 } & $\mathbf{7 5} \mathbf{~}^{\circ} \mathbf{C}$ & $\mathbf{2 2 5}{ }^{\circ} \mathbf{C}$ & $\mathbf{7 5}{ }^{\circ} \mathbf{C}$ & $\mathbf{2 2 5}{ }^{\circ} \mathbf{C}$ \\
\hline 0 & $5.41 \pm 0.15$ & $5.89 \pm 0.25$ & $11.72 \pm 2.83$ & $8.73 \pm 2.93$ \\
5 & $5.00 \pm 0.26$ & $5.62 \pm 0.18$ & $17.02 \pm 4.92$ & $8.72 \pm 3.19$ \\
10 & $5.00 \pm 0.21$ & $5.71 \pm 0.24$ & $16.42 \pm 1.82$ & $11.67 \pm 4.48$ \\
15 & $4.69 \pm 0.20$ & $6.64 \pm 0.33$ & $16.56 \pm 2.12$ & $16.15 \pm 7.98$ \\
20 & $4.44 \pm 0.22$ & $7.27 \pm 0.29$ & $16.06 \pm 0.93$ & $18.92 \pm 2.49$ \\
\hline
\end{tabular}

The water absorption values up to a $10 \%$ dosage of EAFD are approximately constant, and although at $75{ }^{\circ} \mathrm{C}$ is lower, the difference from $225^{\circ} \mathrm{C}$ is not significant. From $15 \%$ of EAFD the tendency of the absorption at both temperatures is the opposite, at $75{ }^{\circ} \mathrm{C}$ it experiences a small decrease and at $225^{\circ} \mathrm{C}$ it increases slightly, producing the greater difference between both, at the dosage of $20 \%$ of EAFD.

EAFD favors the development of flexural strength of geopolymers [17], although the trend differs as a function of the curing temperature. At $75{ }^{\circ} \mathrm{C}$ the flexural strength is independent of the amount of added EAFD, whereas at $225^{\circ} \mathrm{C}$ the increase is gradual, up to $15 \%$ of EAFD the value reached at $75{ }^{\circ} \mathrm{C}$ is equal, being greater for percentages of $20 \%$.

However, other authors [16,17] reported a decrease in the compressive strength of the materials with introduction of EAFD in fly ash based geopolymers, respect a reference without EAFD, for curing temperature below $70^{\circ} \mathrm{C}$. This discrepancy in the trend may be due to the presence of clay, which has influence in the strength development.

In relation to the effect of curing temperature, the samples cured at a higher temperature, show a slight increase of strength for $20 \%$ of EAFD. Therefore, a light influence of the curing temperature on the development of strength when EAFD is introduced into the clay-fly ash based geopolymer have been observed.

As shown in the images taken by the SEM (Figure 2) geopolymers made from EAFD, clay and fly ash are heterogeneous materials. On the one hand, they present zones of high densification, consisting of the aluminosilicate gel formed by the reaction of the amorphous particles of the raw materials used with the activating solution. On the other hand, within these densified zones are unreacted spherical particles, which could be particles belonging to EAFD, fly ash, and clay [16]. Furthermore, as the addition of EAFD is higher it can be observed that the geopolymers are more porous. However, different authors have observed that aging influence the morphology of the material, which is considerably denser without particles $[17,48]$. Regarding the effect of the curing temperature, in the SEM images, no significant differences are observed, except in the geopolymers with $20 \%$ EAFD, where a greater densification is observed at a temperature of $225^{\circ} \mathrm{C}$. This information confirms the result obtained from flexural strength. 


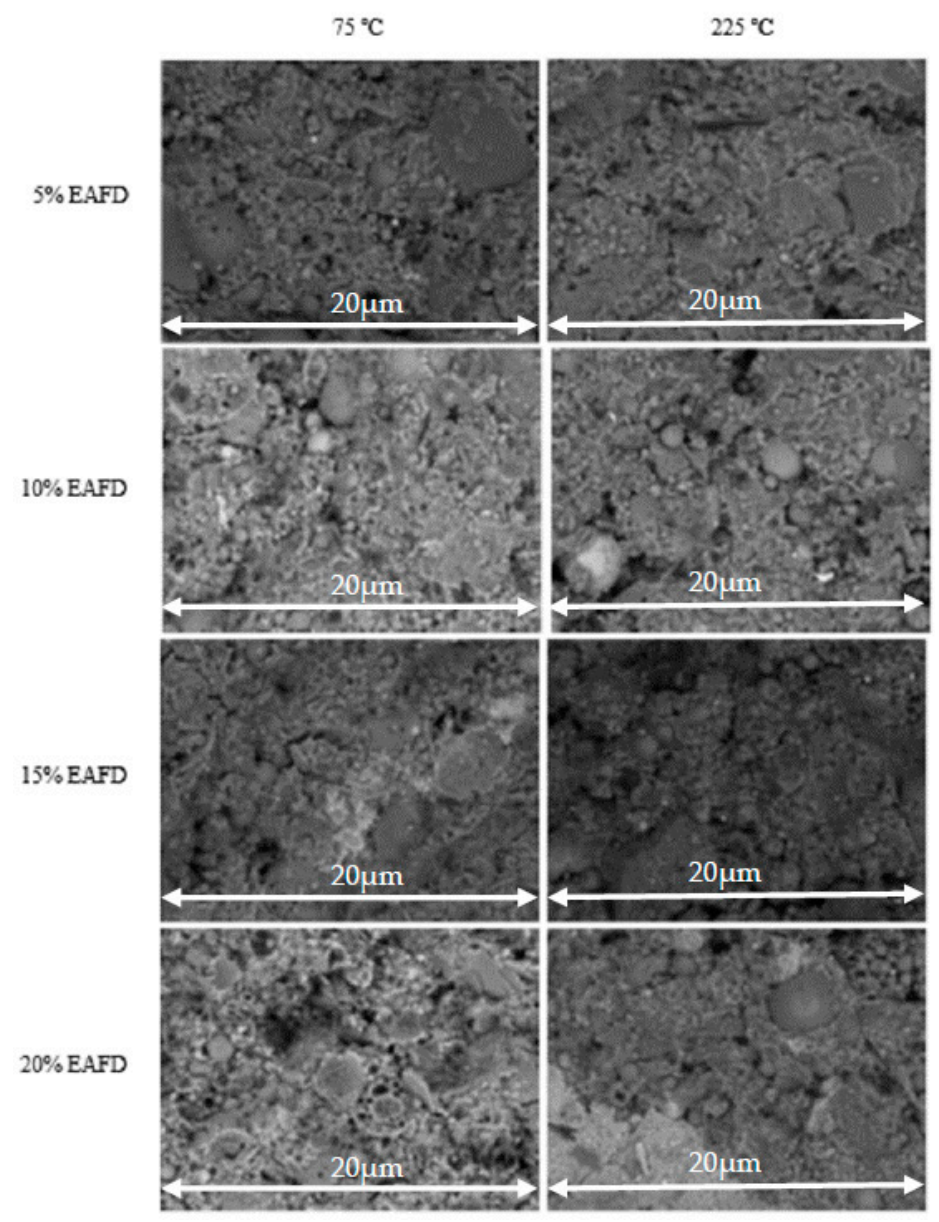

Figure 2. Microstructure of the geopolymer matrices with different dosages of EAFD and curing temperatures.

\subsection{Leaching Tests}

\subsubsection{Mobilization and Availability of Metals}

Only a part of the total content of the elements present in the geopolymeric matrices is available to be leached, and it depends on the phases of the matrix so the concentration on the solution may be significantly lower than the total content [29].

All the analyzed elements $\mathrm{As}, \mathrm{Ba}, \mathrm{Cr}, \mathrm{Cu}, \mathrm{Mo}, \mathrm{Ni}, \mathrm{Pb}, \mathrm{Sb}, \mathrm{Se}, \mathrm{Zn}$, and $\mathrm{Cd}$ except for $\mathrm{Hg}$, present a concentration higher than the quantification limit for both, availability and compliance leaching test (Figure 3). Some of these elements such as $\mathrm{Zn}, \mathrm{Cd}, \mathrm{Cu}$, $\mathrm{Cr}$, and $\mathrm{Pb}$, coming mainly from the EAFD, are retained in the geopolymeric matrix by means of a chemical immobilization in combination with a physical mechanism of microencapsulation [16]. For others such as As, Mo, and Se, there is evidence that chemical immobilization is weak, so unless physical microencapsulation is strong and durable over time geopolymerization is not a suitable treatment for these elements [13].

The elements, which present the greater availability, are $\mathrm{Zn}$-followed by $\mathrm{Pb}, \mathrm{Ba}$, $\mathrm{Cu}$, and $\mathrm{Ni}-$ and to a lesser extent $\mathrm{As}$ and $\mathrm{Cd}$. In general terms, it can be said that the availability of the elements decreases with increasing the curing temperature, since, as it had seen, more densified structures were achieved. There are elements whose availability is not influenced by the amount of EAFD introduced into the material, as $\mathrm{Ba}$ or $\mathrm{Ni}$ and even, in the case of As, it decreases when increasing the dosage of waste. This fact suggests that the arsenic leaching comes from the clay [23].

The results of the equilibrium test show that curing temperature affects mobility more than availability. Up to $10 \%$ EAFD dosages the leaching behavior with temperature is 
similar, while at higher dosages a difference is observed in the trend, being lower in all cases, the higher the curing temperature.

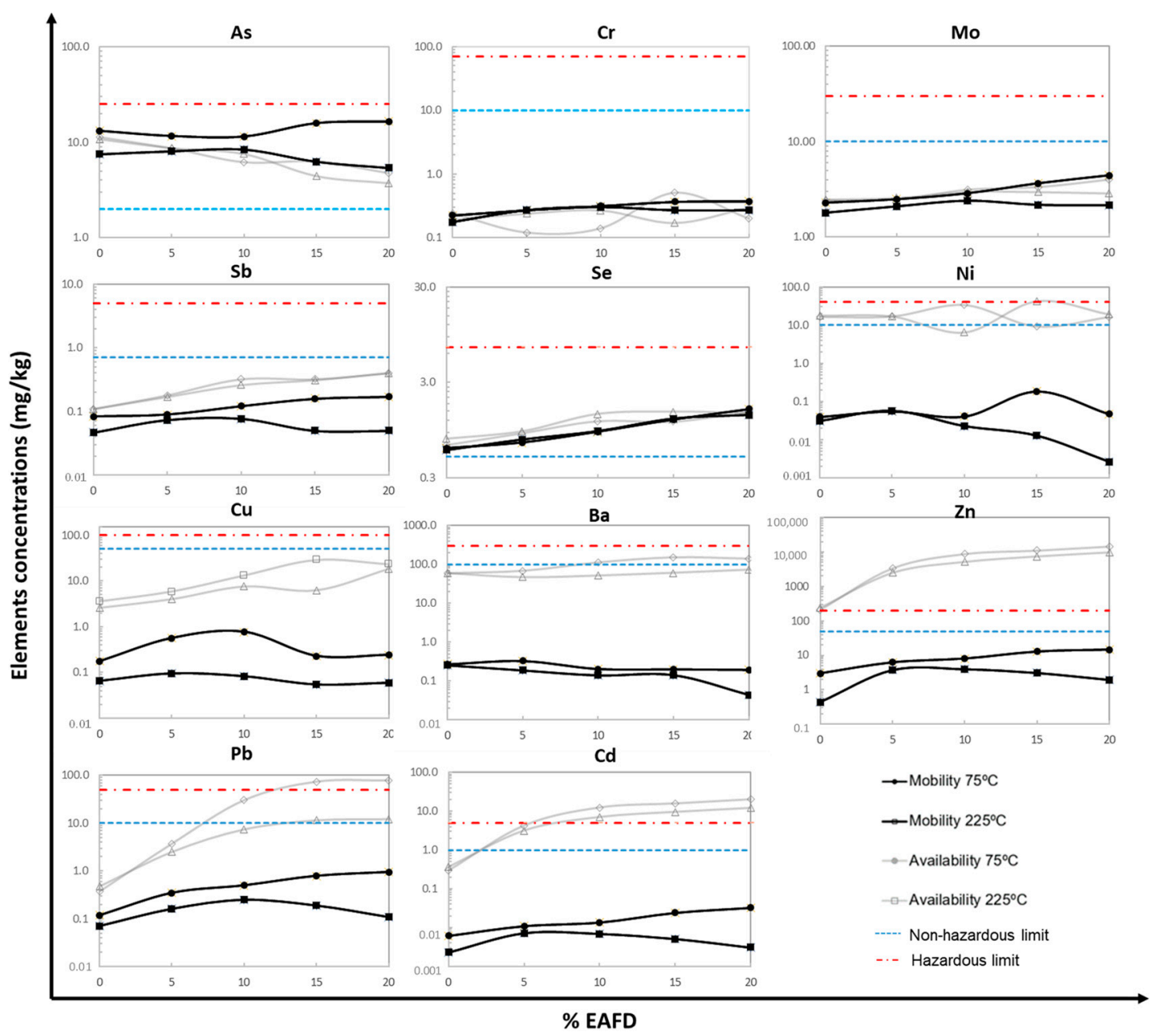

Figure 3. Concentrations $(\mathrm{mg} / \mathrm{kg}$ ) of contaminants in the leachate after the availability and equilibrium/compliance leaching tests of the geopolymers with EAFD at $75^{\circ} \mathrm{C}$ and $225^{\circ} \mathrm{C}$.

The leachates from the equilibrium tests have alkaline $\mathrm{pH}$, due to the release of free alkali from the geopolymers when immersed in deionized water. The $\mathrm{pH}$ remains constant regardless of the dosage of the EAFD and the curing temperature of the geopolymers, between the values 11.75 and 11.99. Due to these high $\mathrm{pH}$ values, most of the oxyanionic elements (as As or Se) leach more in the geopolymeric matrix than in the raw materials. This means that for both elements, the concentration in the leachate exceeds the limit of the regulations for non-hazardous landfill [26]. Although the leaching of As is a fact that is described in several environmental studies of flay ash or clay based geopolymers [23,49-52], authors who introduce EAFD for their immobilization, do not monitor this element, only those associated with the steel dust $(\mathrm{Zn}, \mathrm{Pb}, \mathrm{Cr}, \mathrm{Cd})[16,17,37]$. This also occurs with other authors who use geopolymers to immobilize another hazardous waste, $[34,39,53,54]$ none of which studies the behavior of arsenic.

To promote the immobilization of As, Fernandez-Jimenez and Palomo [51] propose the use of mixed systems together with blast furnace slag, rich in $\mathrm{Ca}$, to help its immobilization.

\subsection{2. $\mathrm{pH}$ dependence Leaching Behavior}

The immobilization of metals in the geopolymeric matrix has been evaluated through the EN 12457-2 compliance test, comparing the leaching results with the limits of the EU landfill regulation, as well as through the availability test. However, these tests are not 
sufficient to describe the wide range of conditions in which the developed material can be used [30].

With the pH-dependent leaching test, the behavior of the immobilized elements of a waste is studied in very different $\mathrm{pH}$ situations (between 2 and 12). Given that, the mobilization of some metals can change even by orders of magnitude in just one $\mathrm{pH}$ unit, it is important to perform this characterization of the material [47].

The concentrations of each of the leached elements are shown in Figures 4 and 5 with different dosages of EAFD as a function of the $\mathrm{pH}$, and the curing temperature of the geopolymer. The elements can be grouped according to their behavior with the $\mathrm{pH}$ in two groups.

The first of the groups is formed by $\mathrm{Cd}, \mathrm{Cr}, \mathrm{Pb}, \mathrm{Zn}, \mathrm{Ba}, \mathrm{Cu}, \mathrm{Sb}$, and $\mathrm{Ni}$ (Figures 4 and 5). These elements leach at acid-neutral $\mathrm{pH}$ for a certain $\mathrm{pH}$ value are hardly mobilized, a behavior that is independent of the dosage of waste and the curing temperature of the geopolymer. For geopolymers without EAFD, leachate concentrations are much lower than when the waste is introduced. In some cases, there is a $\mathrm{pH}$ range where the concentrations present a minimum. Although the behavior of the elements is similar in different matrices, that range in which the $\mathrm{pH}$ is minimal can vary substantially depending on the sorption phases and the complexation reactions that occur with the components of the matrix [55]. In this material, the minimum in the concentrations of $\mathrm{Cr}$ is between $\mathrm{pH} 5-6$, for $\mathrm{Pb}$ and $\mathrm{Cu}$ is 6-7 and for $\mathrm{Zn}, \mathrm{Cd}$, and $\mathrm{Ni}$ is between $8-9$, behaviors similar to those found in $[16,23,56]$.

Ba though leached more at acidic $\mathrm{pH}$ does not present a minimum at any $\mathrm{pH}$ as occurs with the rest of the elements mentioned above. The reference sample without EAFD is the one with the highest concentrations of Ba present in the leachate, decreasing when introducing EAFD, but without significant variations in the quantity introduced.

For As, Mo, and Se, the behavior is contrary to that described for the previous group of elements (Figure 5), presenting the highest concentrations in leachate at basic $\mathrm{pH}$. Increasing the concentration of EAFD in the geopolymer causes that the leaching increase at basic $\mathrm{pH}$. For Mo at $\mathrm{pH}$ between 5.5 and 6, it begins to increase its presence in the leachate but it is not until $\mathrm{pH} 7$ when the influence of the concentration of EAFD begins to appear until $\mathrm{pH}$ 12 , an influence that is minimized by increasing the curing temperature at $225^{\circ} \mathrm{C}$.

Se present slight variations of concentrations in the leachate, being at $\mathrm{pH} 6$ when it undergoes a slight increase and from $\mathrm{pH} 7$ to $\mathrm{pH} 12$ when the influence of the concentration of EAFD becomes evident, the higher concentration the presence of Se in the leachate.

As have a $\mathrm{pH}$ range, from 3 to 8 for As, in which their concentration in the leachate is very low, close to 0 , and for $\mathrm{pH}$ values outside that range reach leachate concentrations of up to $15 \mathrm{mg} / \mathrm{kg}$. The dosage of EAFD in the geopolymers does not have a significant effect on the leaching of this element, because as seen above, arsenic comes mainly from clay.

In the case of these elements, As, Se, and Mo, the natural $\mathrm{pH}$ of the material in the equilibrium test, around 12, coincides with the range of the greatest leaching, for that reason they are the elements that are closest to or exceed the leaching limits for non-hazardous waste landfill [51,52]. 


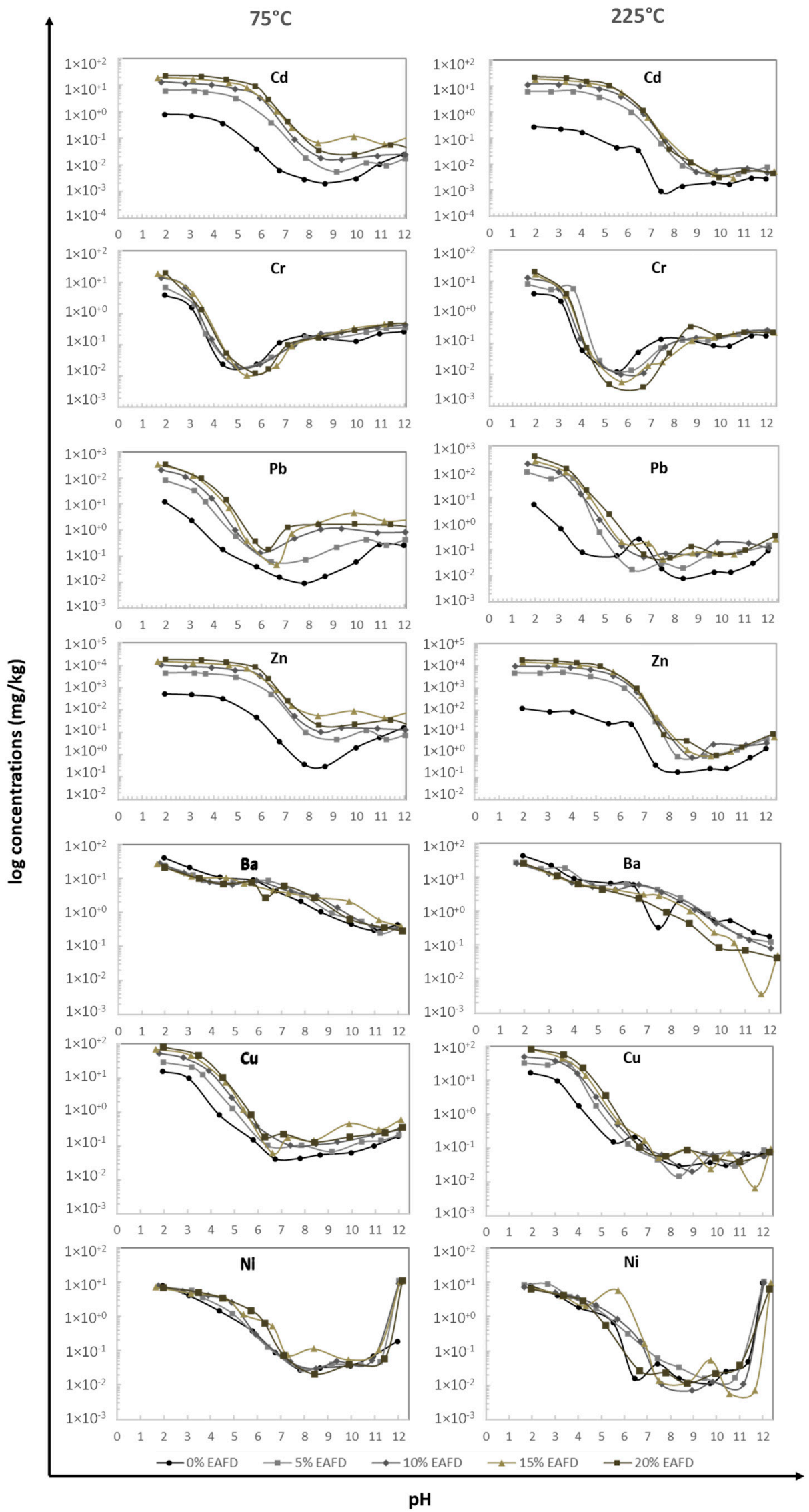

Figure 4. Concentrations $(\mathrm{mg} / \mathrm{kg}$ ) of $\mathrm{Cr}, \mathrm{Pb}, \mathrm{Zn}, \mathrm{Cd}, \mathrm{Ba}, \mathrm{Cu}$, and $\mathrm{Ni}$ in the leachate after the $\mathrm{pH}$ dependence test of the geopolymers with EAFD at $75^{\circ} \mathrm{C}$ and $225^{\circ} \mathrm{C}$. 


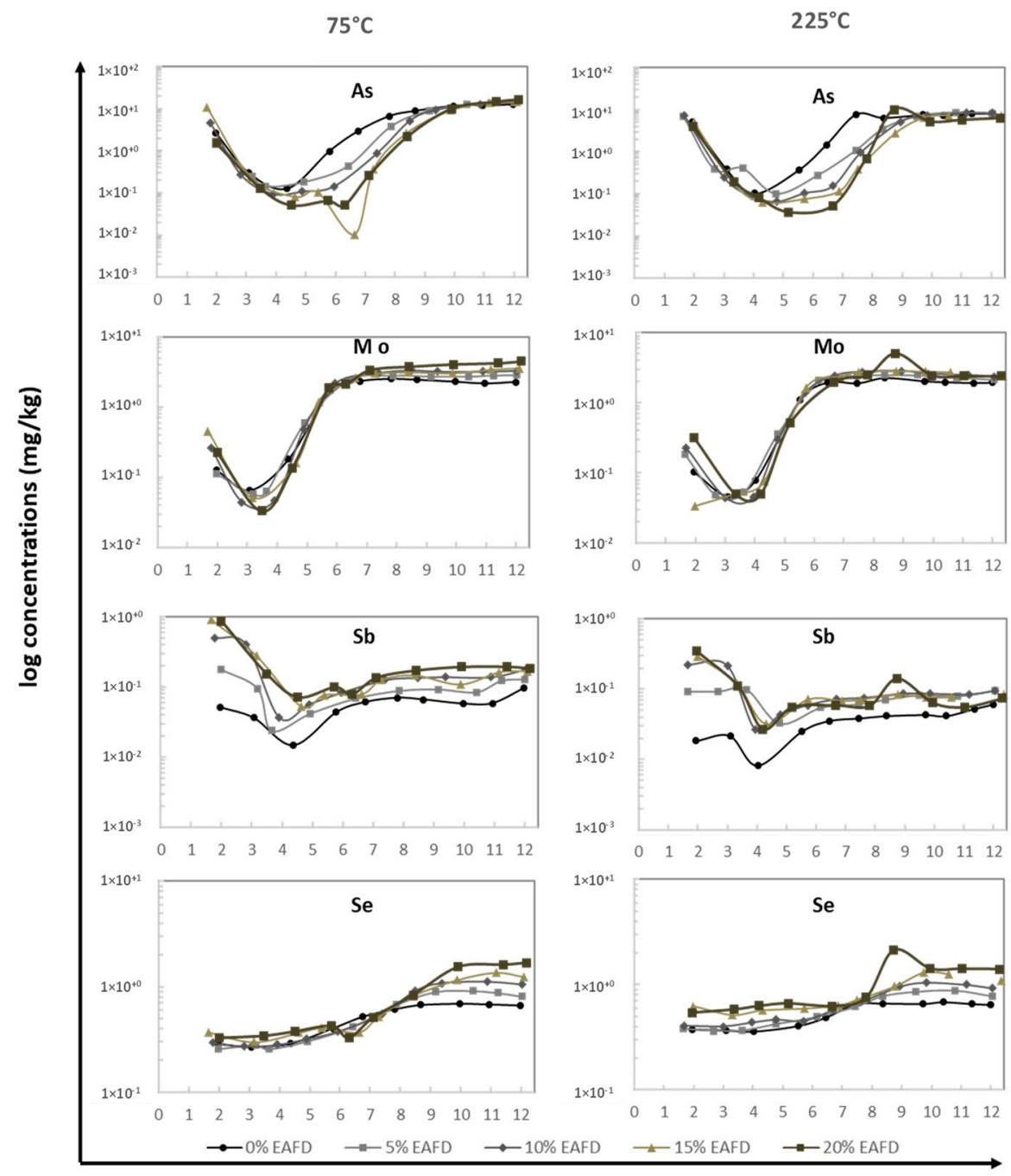

$\mathrm{pH}$

Figure 5. Concentrations $(\mathrm{mg} / \mathrm{kg}$ ) of $\mathrm{As}, \mathrm{Sb}, \mathrm{Mo}$, and Se in the leachate after the $\mathrm{pH}$ dependence test of the geopolymers with EAFD at $75{ }^{\circ} \mathrm{C}$ and $225^{\circ} \mathrm{C}$.

\subsection{Geochemical Modeling}

Leaching of elements from fly ashes are mainly controlled by two different mechanisms that include solubility (dissolution-precipitation) and sorption mechanism [57]. The elements selected to make the geochemical modeling by means of the Visual Minteq 3.1 software were those related to EAFD, as well as the elements that present greater leaching molybdenum, antimony, lead, cadmium, arsenic, selenium, and zinc. Main species, considered elements analyzed as well as mineral phases are described in Table 3.

In Figure 6, the experimental and simulated leaching results of each element using $20 \%$ of EAFD at $75{ }^{\circ} \mathrm{C}$ are shown. Prediction models obtained only considering dissolution/precipitation phenomena differs greatly from experimental results. However, the models obtained considered adsorption or surface complexation of metal onto Fe (HFO) are more in accordance with the experimental results. This means that adsorption is controlling the mobility of all trace elements studied at all $\mathrm{pH}$ values. The adsorption due to iron has a different effect on the elements studied, although it is mainly reflected by retaining the metal by surface adsorption and decreasing its concentration in the leachate [58]. This behavior differs from that of other wastes whose Fe content is lower, and whose leaching is described by solubility-precipitation models [57,59], especially at alkaline $\mathrm{pH}[60]$. 
Table 3. Input parameters of the geochemical modeling.

\begin{tabular}{|c|}
\hline Main Species \\
\hline $\mathrm{MoO}_{4}{ }^{2-} ; \mathrm{Sb}(\mathrm{OH})_{3} ; \mathrm{Sb}(\mathrm{OH})^{2+} ; \mathrm{Pb}^{2+} ; \mathrm{Cd}^{2+} ; \mathrm{AsO}_{4}^{3-} ; \mathrm{HSeO}_{3}{ }^{1-} ; \mathrm{SeO}_{3}{ }^{2-} ; \mathrm{SeO}_{4}{ }^{2-} ; \mathrm{HSeO}_{4}^{1-} ; \mathrm{Zn}^{2+}$ \\
\hline Elements \\
\hline $\mathrm{Mo}, \mathrm{Sb}, \mathrm{Pb}, \mathrm{Cd}, \mathrm{As}, \mathrm{Se}, \mathrm{Zn}$ \\
\hline Mineral Phases * \\
\hline 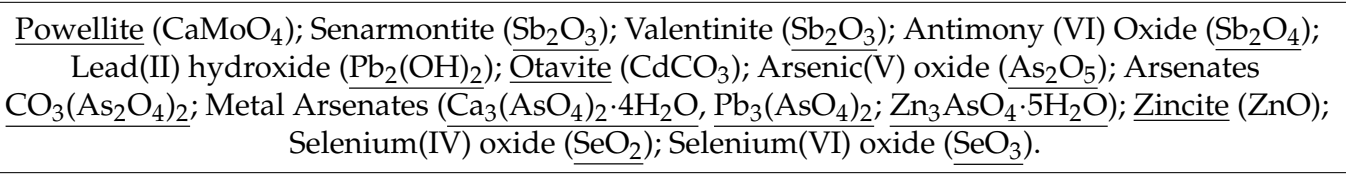 \\
\hline Mineral Adsorption \\
\hline $\begin{array}{c}\text { Diffuse layer Surface complexation model of Fe- and Al-/hydro) oxides Surface (HFO) mineral } \\
\text { adsorption }\end{array}$ \\
\hline
\end{tabular}

Elements that are close to oxygen in electronegativity tend to form oxyanions i.e., the transition metal Mo which from $\mathrm{MoO}^{2-}{ }_{4}$ [58]. Looking at Figure 6, the maximum solubility was found at $\mathrm{pH}$ 10. The alkaline V-shape for Mo leaching might indicate binding of Mo to sulphoaluminates. Considering the geochemical behavior, Powellite $\left(\mathrm{CaMoO}_{4}\right)$ precipitated in all cases. Based on the existing findings, Mo was subjected to geochemical speciation modeling, assuming its presence as oxyanion.

Leaching behavior of $\mathrm{Cd}$ and $\mathrm{Zn}$ as a function of $\mathrm{pH}$ follows a cationic pattern. For elements controlled by solubility or sorption, cationic pattern involves increasing dissolution and/or desorption of metal-bearing mineral phases as the $\mathrm{pH}$ decreases and diminishing leaching due to precipitation and/or increasing sorption as the $\mathrm{pH}$ increases. As $\mathrm{pH}$ decreases the leaching amount of the cationic elements increase due to increasing attacking on the metal-bearing mineral phases as acid strength increases [59]. Sulphate and carbonate minerals are the two main minerals that may precipitate with leached $\mathrm{Cd}$ element. In this case, the carbonate can control the leaching of $\mathrm{Cd}$ in the aqueous solution. In this case, Otavite $\left(\mathrm{CdCO}_{3}\right)$ precipitates at all $\mathrm{pH}$ ranges [33].

Leaching of $\mathrm{Pb}$ is controlled by $\mathrm{Pb}(\mathrm{OH})_{2}$ in accordance with previous studies appearing on the literature $[57,60]$. Such a mechanism corresponds to cationic element mobilizing in the form of $\mathrm{Pb}^{+2}$.

It is expected that the leaching of $\mathrm{Zn}$ be controlled by the dissolution/precipitation reaction in the soil matrix at any $\mathrm{pH}$ condition. In this case, zincite $(\mathrm{ZnO})$ may control the leaching of the geopolymeric matrix in the $\mathrm{pH}$ range of 2-9 (Figure 5).

Oxyanion pattern was remarkable for As which is in accordance with the literature [59]. The same occurs with the Se within the studied $\mathrm{pH}$ range. The leaching behavior of both elements as a function of $\mathrm{pH}$ can be explained by the species in the leachate and $\mathrm{pH}$ -dependent surface charge of fly ash. Negatively charged oxyanions, As and Se in the form of $\mathrm{SeO}_{3}{ }^{2-}, \mathrm{HSeO}_{3}{ }^{1-}$, and $\mathrm{AsO}_{4}{ }^{3-}$ precludes adsorption onto the negatively charged surface of the geopolymer contributing to higher As and Se concentrations at alkaline $\mathrm{pH}[59]$.

Apart from the geochemical models plotted in Figure 6, Visual Minteq also provides information about the speciation distributions in terms of percentage of each specie on a molar basis. The trace pollutants $\mathrm{Cd}, \mathrm{Mo}, \mathrm{Sb}, \mathrm{As}, \mathrm{Se}, \mathrm{Zn}$, and $\mathrm{Pb}$ speciation was visualized in Figure 6 for the geopolymers with $20 \%$ of steel powder at $75^{\circ} \mathrm{C}$ in all the studied pH range. It seems how the cationic elements such as $\mathrm{Cd}, \mathrm{Zn}$, and $\mathrm{Pb}$ are mainly released as their respective cations (+2) oxidation state. Nevertheless, oxyanions As, Mo, and Se, arsenates, molybdates, and selenates are responsible for the As, Mo, and Se leaching at all $\mathrm{pH}$ values. 

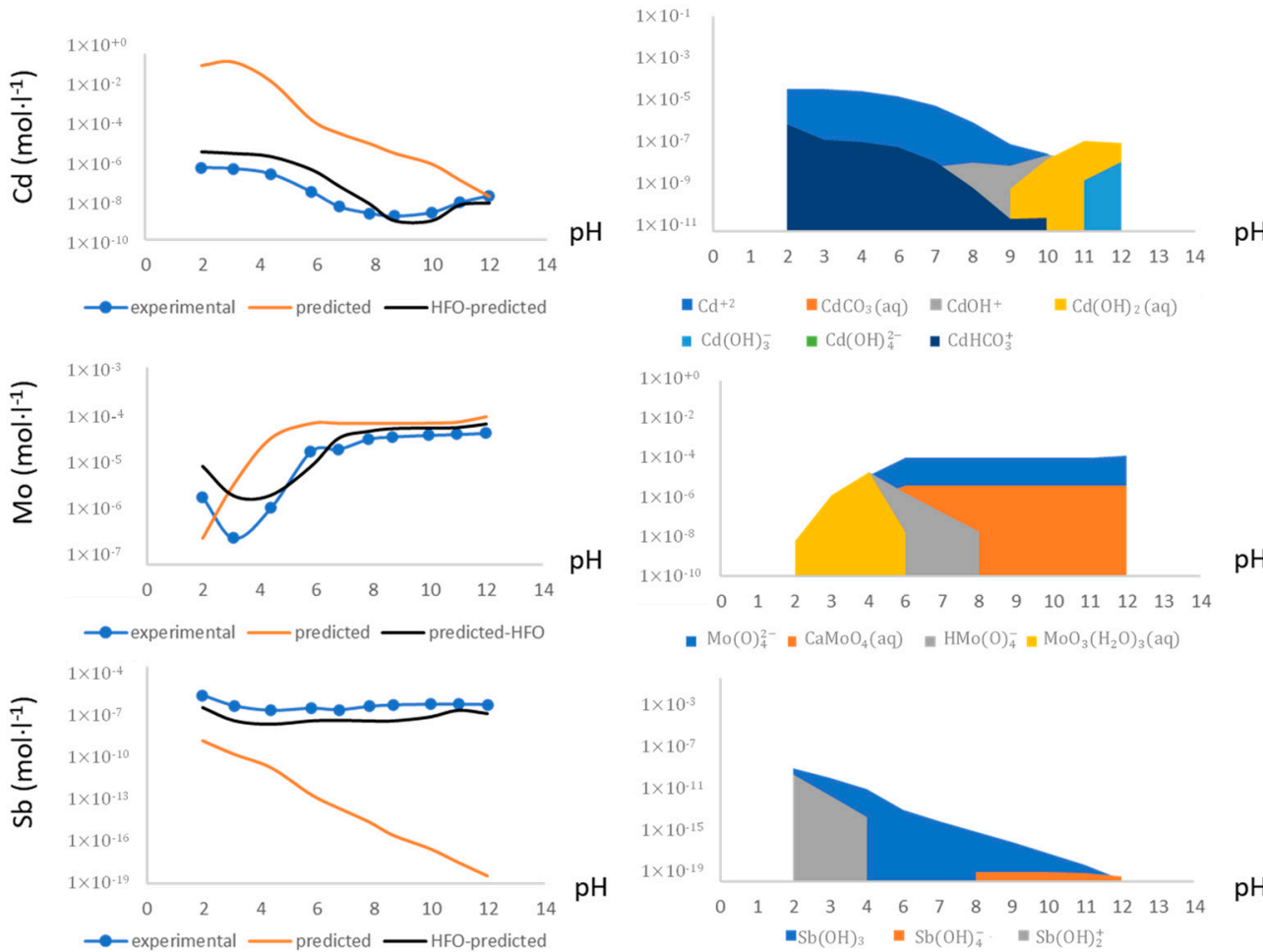

- $\mathrm{Mo}(\mathrm{O})_{4}^{2-} \| \mathrm{CaMoO}_{4}(\mathrm{aq}) \quad$ | $\mathrm{HMo}(\mathrm{O})_{4}^{-} \| \mathrm{MoO}_{3}\left(\mathrm{H}_{2} \mathrm{O}\right)_{3}(\mathrm{aq})$
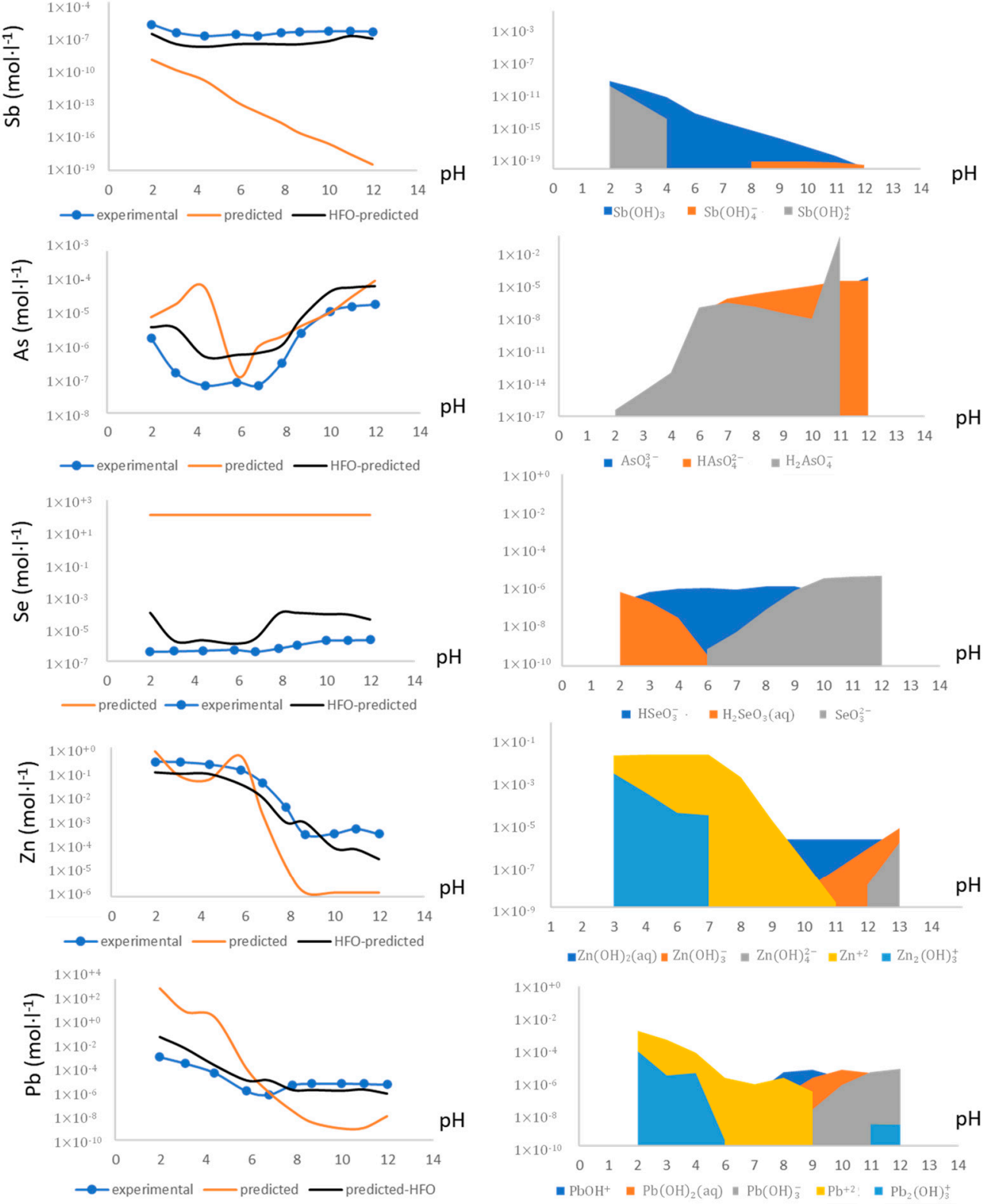

Figure 6. Measured and predicted leaching behavior of the selected trace elements as a function of $\mathrm{pH}$ (on the left); chemical speciation modeling of the selected trace elements. 


\section{Conclusions}

The immobilization of pollutants from EADF through its introduction into ceramic geopolymers, for use in construction, has been evaluated in this work. Increasing amounts of clay have been replaced by EAFD as raw material (from 0 to $20 \%$ ), and the geopolymers have been cured at two different temperatures. The impact on technological and environmental properties have been evaluated. The introduction of EAFD into the geopolymer matrix promotes the development of the flexural strength of the geopolymer regardless of curing temperature. Furthermore, the best results of water absorption were achieved with high dosage of dust and at low temperatures.

From the environmental point of view, metals related to EAFD, such as $\mathrm{Zn}, \mathrm{Pb}$, or $\mathrm{Cu}$, are retained in the geopolymer matrix, and the mobility of these elements decreases at highest curing temperature. However, oxyanionic elements, such as As or Se, due to the high $\mathrm{pH}$ that alkali produces when is introduced into water, present a very high concentration, which even exceeds the limits for non-hazardous waste disposal. Arsenic comes mainly from clay, and it barely has a concentration of amorphous silica that can geopolymerize, so the role played by clay and its possible replacement should be analyzed in future research.

The use of a speciation model helps to predict the behavior and to understand the leaching mechanism. As expected by the high iron content in the EAFD, the iron complexes on the surface of the material play an important role in the immobilization of metals in this kind of matrix.

Author Contributions: Investigation, formal analysis, writing-original draft preparation: E.C.; Methodology, investigation: J.D.; Software, writing—original draft preparation: T.L.; Methodology, investigation: M.d.C.D.-F.; Conceptualization, funding acquisition, and project administration: A.A.; All authors have read and agreed to the published version of the manuscript.

Funding: This work was funded by the University of Cantabria "Proyecto Puente 2017" through a grant (PI A. Andres) under SODERCAN and ERDF Regional Operational Programme 2014-2020.

Institutional Review Board Statement: Not applicable.

Informed Consent Statement: Not applicable.

Data Availability Statement: The data presented in this study are available on reasonable request from the corresponding authors.

Acknowledgments: Acknowledge the technical support to J.M. Chimenos and R. del Valle from the University of Barcelona, and C. Thomas and M. de Pedro from the University of Cantabria. Thank the company Reciclados De Cabezon S.l. - (Cabezón de la Sal, Cantabria, Spain) for supplying the materials used in this work.

Conflicts of Interest: The authors declare no conflict of interest.

\section{References}

1. De Buzin, P.J.W.K.; Heck, N.C.; Vilela, A.C.F. EAF dust: An overview on the influences of physical, chemical and mineral features in its recycling and waste incorporation routes. J. Mater. Res. Technol. 2017, 6, 194-202. [CrossRef]

2. Sebag, M.G.; Korzenowski, C.; Bernardes, A.M.; Vilela, A.C. Evaluation of environmental compatibility of EAFD using different leaching standards. J. Hazard. Mater. 2009, 166, 670-675. [CrossRef] [PubMed]

3. Global Steel Dust Ltd. Available online: https://www.bayt.com/en/company/global-steel-dust-gulf-1lc-1503840/ (accessed on 20 November 2020).

4. Fuessle, R.W.; Taylor, M.A. Long-Term Solidification/Stabilization and Toxicity Characteristic Leaching Procedure for an Electric Arc Furnace Dust. J. Envviron. Eng. 2004, 130, 492-498. [CrossRef]

5. Sofilić, T.; Rastovčan-Mioč, A.; Cerjan-Stefanović, Š.; Novosel-Radović, V.; Jenko, M. Characterization of steel mill electric-arc furnace dust. J. Hazard. Mater. 2004, 109, 59-70. [CrossRef]

6. Maslehuddin, M.; Awan, F.R.; Shameem, M.; Ibrahim, M.; Ali, M.R. Effect of electric arc furnace dust on the properties of OPC and blended cement concretes. Constr. Build. Mater. 2011, 25, 308-312. [CrossRef]

7. The European Commission. Commission Decision 2014/955/EU-List of Waste; The European Commission: Brussels, Belgium, 2014.

8. Andres, A.; Ruiz-Labrador, B.; Coz, A.; Viguri, J. Testing of solidified-stabilized products at industrial-scale prior to disposal using new compliance leaching tests. In Proceedings of the WASCON Congress, Belgrade, Serbia, 30 May-2 June 2006. 
9. Coz, A.; Ruiz-Labrador, B.; Viguri, J.; Andres, A. Factorial Experimental Design of Batch Leaching Tests in Stabilised/Solidified Metallic Waste. In Proceedings of the ISWA World Congress, Amsterdam, The Netherland, 24-27 September 2007.

10. Remus, R.; Aguado, M.; Roudier, S.; Delgado, L. Best Available Techniques (BAT) Reference Document for Iron and Steel Production; 212AD; Publications Office of the European Union: Luxembourg, 2012.

11. Lanzerstorfer, C. Electric arc furnace (EAF) dust: Application of air classification for improved zinc enrichment in in-plant recycling. J. Clean. Prod. 2018, 174, 1-6. [CrossRef]

12. Elías, X. Residuos Sólidos Urbanos y Fangos Depuradora; Ed. Díaz de Santos: Madrid, Spain, 2012.

13. Kavouras, P.; Kehagias, T.; Tsilika, I.; Kaimakamis, G.; Chrissafis, K.; Kokkou, S.; Papadopoulos, D.; Karakostas, T. Glass-ceramic materials from electric arc furnace dust. J. Hazard. Mater. 2007, 139, 424-429. [CrossRef]

14. Magalhães, M.d.S.; Faleschini, F.; Pellegrino, C.; Brunelli, K. Influence of alkali addition on the setting and mechanical behavior of cement pastes and mortars with electric arc furnace dust. Constr. Build. Mater. 2019, 214, 413-419. [CrossRef]

15. Massarweh, O.; Maslehuddin, M.; Al-Dulaijan, S.U.; Shameem, M.; Ahmad, S. Development of a concrete set retarder utilizing electric arc furnace dust. Constr. Build. Mater. 2020, 255, 119378. [CrossRef]

16. Nikolic, I.; Durovic, D.; Blecic, D.; Zejak, R.; Karanovic, L.; Mitsche, S.; Radmilovic, V.R. Geopolymerization of coal fly ash in the presence of electric arc furnace dust. Miner. Eng. 2013, 49, 24-32. [CrossRef]

17. Arnold, M.C.; de Vargas, A.S.; Bianchini, L. Study of electric-arc furnace dust (EAFD) in fly ash and rice husk ash-based geopolymers. Adv. Powder Technol. 2017, 28, 2023-2034. [CrossRef]

18. Pacheco-Torgal, F.; Labrincha, J.A.; Leonelli, C.; Palomo, A.; Chindaprasirt, P. Handbook of Alkali-Activated Cements, Mortars and Concretes; Woodhead Publishing, Ltd.: Sawston, UK, 2014.

19. Davidovits, J. Geopolymer: Chemistry and Applications; Institute Geopolymere: Saint-Quentin, France, 2011.

20. Provis, J.L.; Van Deventer, J.S.J. Geopolymers: Structures, Processing, Properties and Industrial Applications; Woodhead Publishing: Sawston, UK, 2009.

21. Imtiaz, L.; Rehman, S.K.U.; Ali Memon, S.; Khizar Khan, M.; Faisal Javed, M. A Review of Recent Developments and Advances in Eco-Friendly Geopolymer Concrete. Appl. Sci. 2020, 10, 7838. [CrossRef]

22. Fang, W.; Qi, G.; Wei, Y.; Kosson, D.S.; van der Sloot, H.A.; Liu, J. Leaching characteristic of toxic trace elements in soils amended by sewage sludge compost: A comparison of field and laboratory investigations. Envviron. Pollut. 2018, 237, 244-252. [CrossRef] [PubMed]

23. Sun, Z.; Vollpracht, A.; van der Sloot, H.A. pH dependent leaching characterization of major and trace elements from fly ash and metakaolin geopolymers. Cem. Concr. Res. 2019, 125, 105889. [CrossRef]

24. Saveyn, H.; Eder, P.; Garbarino, E.; Muchova, L.; Hjelmar, O.; Van Der Sloot, H.A.; Comans, R.; Van Zomeren, A.; Hyks, J.; Oberender, A. Study on Methodological Aspects Regarding Limit Values for Pollutants in Aggregates in the Context of the Possible Development of End-of-Waste Criteria under the EU Waste Framework Directive. 2014. Available online: https:/ / ec.europa.eu/jrc/en/publication/eur-scientific-and-technical-research-reports/study-methodological-aspectsregarding-limit-values-pollutants-aggregates-context-possible (accessed on 20 November 2020).

25. Bandow, N.; Gartiser, S.; Ilvonen, O.; Schoknecht, U. Evaluation of the impact of construction products on the environment by leaching of possibly hazardous substances. Envviron. Sci. Eur. 2018, 30, 14. [CrossRef]

26. European Parliament and Council. Directive (EU) 2018/850 of the European Parliament and of the Council of 30 May 2018 amending Directive 1999/31/EC on the landfill of waste. Off. J. Eur. Union 2018, L150, 100-108.

27. EN 12920:2007+A1:2009. Characterization of waste-Methodology for the Determination of the Leaching Behaviour of Waste under Specified Condition 2009. Spanish Technical Standard. Available online: http:/ / www.une.org (accessed on 20 September 2019).

28. Grathwohl, P.; Susset, B. Comparison of percolation to batch and sequential leaching tests: Theory and data. Waste Manag. 2009, 29, 2681-2688. [CrossRef]

29. Quina, M.J.; Bordado, J.C.M.; Quinta-Ferreira, R.M. The influence of $\mathrm{pH}$ on the leaching behaviour of inorganic components from municipal solid waste APC residues. Waste Manag. 2009, 29, 2483-2493. [CrossRef]

30. Kosson, D.S.; Van der Sloot, H.A.; Sanchez, F.; Garrabrants, A.C. An Integrated Framework for Evaluating Leaching in Waste Management and Utilization of Secondary Materials. Envviron. Eng. Sci. 2002, 19, 159-204. [CrossRef]

31. Coz, A.; Ruiz-Labrador, B.; Alonso-Santurde, R.; Coronado, M.; Andres, A. Leaching behaviour methodology as a tool for stabilised/solidified metallic waste characterisation. In Proceedings of the WASCON 2012 Conference Proceedings, Göteborg, Sweden, 30 May-1 June 2012.

32. Hjelmar, O.; Wahlström, M.; Van Zomeren, A.; Kalbe, U.; Grathwohl, P.; Abdelghafour, M.; Schiopu, N. Robustness Validation of TS-2 and TS-3 Developed by CEN/TC351/WG1 to Assess Release from Products to Soil, Surface Water and Groundwater. 2013. Available online: https://www.nen.nl/media/Overig/WG_1_Robustness_Validation_Report_-_TS-2_and_TS-3_-_Leaching_ methods.pdf (accessed on 20 January 2020).

33. Jarošíková, A.; Ettler, V.; Mihaljevič, M.; Kříbek, B.; Mapani, B. The pH-dependent leaching behavior of slags from various stages of a copper smelting process: Environmental implications. J. Envviron. Manag. 2017, 187, 178-186. [CrossRef]

34. Pandey, B.; Kinrade, S.D.; Catalan, L.J.J. Effects of carbonation on the leachability and compressive strength of cement-solidified and geopolymer-solidified synthetic metal wastes. J. Envviron. Manag. 2012, 101, 59-67. [CrossRef] [PubMed]

35. Van der Sloot, H.A.; Kosson, D.S.; van Zomeren, A. Leaching, geochemical modelling and field verification of a municipal solid waste and a predominantly non-degradable waste landfill. Waste Manag. 2017, 63, 74-95. [CrossRef] [PubMed] 
36. Liu, B.; Li, J.; Wang, Z.; Zeng, Y.; Ren, Q. Long-term leaching characterization and geochemical modeling of chromium released from AOD slag. Envviron. Sci. Pollut. Res. 2020, 27, 921-929. [CrossRef] [PubMed]

37. Fernández Pereira, C.; Luna, Y.; Querol, X.; Antenucci, D.; Vale, J. Waste stabilization/solidification of an electric arc furnace dust using fly ash-based geopolymers. Fuel 2009, 88, 1185-1193. [CrossRef]

38. Almalkawi, A.T.; Balchandra, A.; Soroushian, P. Potential of Using Industrial Wastes for Production of Geopolymer Binder as Green Construction Materials. Constr. Build. Mater. 2019, 220, 516-524. [CrossRef]

39. Wang, L.; Geddes, D.A.; Walkley, B.; Provis, J.L.; Mechtcherine, V.; Tsang, D.C.W. The role of zinc in metakaolin-based geopolymers. Cem. Concr. Res. 2020, 136, 106194. [CrossRef]

40. Tome, S.; Etoh, M.A.; Etame, J.; Sanjay, K. Characterization and leachability behaviour of geopolymer cement synthesised from municipal solid waste incinerator fly ash and volcanic ash blend. Recycling 2018, 3, 50. [CrossRef]

41. Liu, D.G.; Ke, Y.; Min, X.B.; Liang, Y.J.; Wang, Z.B.; Li, Y.C.; Fei, L.W.; Xu, H.; Jiang, G.H. Cotreatment of MSWI fly ash and granulated lead smelting slag using a geopolymer system. Int. J. Environ Res. Public Health. 2019, 16, 156. [CrossRef]

42. Azarsa, P.; Gupta, R. Freeze-Thaw performance characterization and leachability of potassium-based geopolymer concrete. J. Compos. Sci. 2020, 4, 45. [CrossRef]

43. Loncnar, M.; van der Sloot, H.A.; Mladenovič, A.; Zupančič, M.; Kobal, L.; Bukovec, P. Study of the leaching behaviour of ladle slags by means of leaching tests combined with geochemical modelling and mineralogical investigations. J. Hazard. Mater. 2016, 317. [CrossRef]

44. Wang, D.; Wang, Q.; Xue, J. Reuse of hazardous electrolytic manganese residue: Detailed leaching characterization and novel application as a cementitious material. Resour. Conserv. Recycl. 2020, 154, 104645. [CrossRef]

45. Wang, L.; Chen, Q.; Jamro, I.A.; Li, R.; Li, Y.; Li, S.; Luan, J. Geochemical modeling and assessment of leaching from carbonated municipal solid waste incinerator (MSWI) fly ash. Environ. Sci. Pollut. Res. 2016, 23, 12107-12119. [CrossRef] [PubMed]

46. Nikolići, I.; Dsignurović, D.; Tadić, M.; Blečić, D.; Radmilović, V. Immobilization of zinc from metallurgical waste and water solutions using geopolymerization technology. E3S Web Conf. 2013, 1, 41026. [CrossRef]

47. Coronado, M. Foundry Wastes as New Resources in Ceramic Processes. Ph.D. Thesis, Universidad de Cantabria, Cantabria, Spain, 2014.

48. De Vargas, A.S.; Dal Molin, D.C.C.; Vilela, A.C.F.; Silva, F.J.D.; Pavão, B.; Veit, H. The effects of $\mathrm{Na}_{2} \mathrm{O} / \mathrm{SiO}_{2} \mathrm{molar}$ ratio, curing temperature and age on compressive strength, morphology and microstructure of alkali-activated fly ash-based geopolymers. Cem. Concr. Compos. 2011, 33, 653-660. [CrossRef]

49. Izquierdo, M.; Querol, X.; Davidovits, J.; Antenucci, D.; Nugteren, H.; Fernández-Pereira, C. Coal fly ash-slag-based geopolymers: Microstructure and metal leaching. J. Hazard. Mater. 2009, 166, 561-566. [CrossRef]

50. Álvarez-Ayuso, E.; Querol, X.; Plana, F.; Alastuey, A.; Moreno, N.; Izquierdo, M.; Font, O.; Moreno, T.; Diez, S.; Vázquez, E.; et al. Environmental, physical and structural characterisation of geopolymer matrixes synthesised from coal (co-)combustion fly ashes. J. Hazard. Mater. 2008, 154, 175-183. [CrossRef]

51. Fernández-Jiménez, A.; Palomo, A.; Macphee, D.E.; Lachowski, E.E. Fixing arsenic in alkali-activated cementitious matrices. J. Am. Ceram. Soc. 2005, 88, 1122-1126. [CrossRef]

52. Maldonado-Alameda, À.; Giro-Paloma, J.; Alfocea-Roig, A.; Formosa, J.; Chimenos, J.M. Municipal Solid Waste Incineration Bottom Ash as Sole Precursor in the Alkali-Activated Binder Formulation. Appl. Sci. 2020, 10, 4129. [CrossRef]

53. Zhang, P.; Muhammad, F.; Yu, L.; Xia, M.; Lin, H.; Huang, X.; Jiao, B.; Shiau, Y.C.; Li, D. Self-cementation solidification of heavy metals in lead-zinc smelting slag through alkali-activated materials. Constr. Build. Mater. 2020, 249, 118756. [CrossRef]

54. Abdel-Gawwad, H.A.; Mohammed, M.S.; Zakey, S.E. Preparation, performance, and stability of alkali-activated-concrete waste-lead-bearing sludge composites. J. Clean. Prod. 2020, 259, 120924. [CrossRef]

55. Heasman, L.; van der Sloot, H.; Quevauviller, H. Harmonization of Leaching/Extraction tests. Stud. Environ. Sci. 1997, 70.

56. Xu, P.; Zhao, Q.; Qiu, W.; Xue, Y. The evaluation of the heavy metal leaching behavior of MSWI-FA added alkali-activated materials bricks by using different leaching test methods. Int. J. Environ. Res. Public Health 2019, 16, 1151. [CrossRef] [PubMed]

57. Zhang, Y.; Cetin, B.; Likos, W.J.; Edil, T.B. Impacts of $\mathrm{pH}$ on leaching potential of elements from MSW incineration fly ash. Fuel 2016, 184, 815-825. [CrossRef]

58. Engelsen, C.J.; Van Der Sloot, H.A.; Wibetoe, G.; Justnes, H.; Lund, W.; Stoltenberg-Hansson, E. Leaching characterisation and geochemical modelling of minor and trace elements released from recycled concrete aggregates. Cem. Concr. Res. 2010, 40, 1639-1649. [CrossRef]

59. Komonweeraket, K.; Benson, C.H.; Edil, T.B.; Bleam, W.F. Leaching behavior and mechanisms controlling the release of elements from soil stabilized with fly ash. In Proceedings of the Geo-Frontiers 2011: Advances in Geotechnical Engineering, Dallas, TX, USA, 13-16 March 2011; pp. 1101-1110.

60. Cui, Y.; Chen, J.; Zhang, Y.; Peng, D.; Huang, T.; Sun, C. pH-Dependent Leaching Characteristics of Major and Toxic Elements from Red Mud. Int. J. Environ. Res. Public Health 2019, 16, 2046. [CrossRef] [PubMed] 